\title{
Multiple Myeloma Relapsed with Skull Involvement in Plasmacytoma
}

Yusuf Kayar $^{1 *}$, Nuket Bayram Kayar ${ }^{2}$, Iskender Ekinci ${ }^{1}$, Ganime Coban ${ }^{3}$ and Nurcan Unver ${ }^{3}$

${ }^{1}$ Department of Internal Medicine, Bezmialem Vakıf University, Istanbul, Turkey

${ }^{2}$ Department of Family Medicine, Bagcilar Education and Research Hospital, Istanbul, Turkey

${ }^{3}$ Department of Pathology, Bezmialem Vakıf University, Istanbul, Turkey

*Corresponding author: Yusuf Kayar, Department of Internal Medicine, Bezmialem Vakıf University, Istanbul, Turkey, Tel: +90 212453 1700; E-mail: ykayar@yahoo.com

Received date: July 29, 2016; Accepted date: August 03, 2016; Published date: August 05, 2016

Copyright: (c) 2016 Kayar Y, et al. This is an open-access article distributed under the terms of the Creative Commons Attribution License, which permits unrestricted use, distribution, and reproduction in any medium, provided the original author and source are credited.

\begin{abstract}
Extra medullary plasmacytomas occurring as solitary (primary) tumours or secondary manifestations of multiple myeloma most often involve the upper airways and paranasal sinuses. The skull is one of the rarest sites of extra medullary plasmacytoma. Myelomatous deposits in dural reflections distant from the bony skull, i.e. tentorium and falx, are rarer, and probably result from dissection along layers of meninges. Osseous and pachymeningeal masses in the cranial vault or in the skull base may result in tumefaction, pain, headache, single or multiple cranial nerve palsies or seizure. A case of multiple myeloma relapsed with extra medullary plasmacytoma in the skull, forehead and ear involvement is reported.
\end{abstract}

Keywords: Multiple myeloma; Plasmacytoma; Skull involvement

\section{Introduction}

Extra medullary plasmacytomas (EP) are rare lesions, diagnosed either as a part of a generalized disease (Multiple myeloma) or a local entity. It is possible for an apparent solitary plasmacytoma to be the first presenting feature of generalized disease or apparent during the course. EP occurring as solitary (primary) tumours or secondary manifestations of multiple myeloma most often involves the upper airways and paranasal sinuses [1]. The skull is one of the rarest sites of EP. We herein reported a case report of multiple myeloma relapsed with EP in the skull, forehead and ear involvement.

\section{Case Report}

The patient was hospitalized with lumbar pain and leg pain one year ago. His tests revealed that; leukocyte $6.500 \mathrm{~mm}^{3}$, hemoglobin 12.7 $\mathrm{gr} / \mathrm{dl}$, platelet $212.000 \mathrm{~mm}^{3}$, creatinine $0.9 \mathrm{gr} / \mathrm{dl}$, LDH $200 \mathrm{U} / \mathrm{L}$, calcium $9.7 \mathrm{mg} / \mathrm{dl}$, beta-2-microglobulin $3.15 \mathrm{mg} / \mathrm{L}$, and M-spike 1.39 $\mathrm{g} / \mathrm{dl}$. The patient's serum-urine immunofixation revealed IgA type monoclonal gammopathy in the serum and kappa type free light chain in the urine. The bone marrow biopsy revealed neoplastic plasma cell infiltration with interstitial character, and plasma cells in a ratio of $20 \%$. The patient was started Vincristine, Adriamycin, Dexamethasone (VAD) treatment. The patient did not respond sufficiently to two cures of VAD, and he was given 6 cures of Bortezomib and Dexamethasone treatments. Full response was obtained after the treatment. When stem cell mobilization could not be provided with Granulocyte colonystimulating factor (G-CSF), the patient was planned to receive stem cell mobilization with cyclophosphamide and etoposide, and was discharged for later outpatient procedures. After two months, patient developed swellings on his head, and it was thought that his condition could have progressed, and he was hospitalized for chemotherapy and stem cell mobilization. The tests did not reveal any pathology suggesting systemic involvement. IgA kappa type monoclonal gammopathy was found in serum and urine. Cells were collected with cyclophosphamide and etoposide. It was seen that the swellings on his head completely disappeared after chemotherapy. The patient, who did not come for checks after the cells were collected. After three months was hospitalized again because he developed new swellings on his head. His physical examination revealed $2 \times 3 \mathrm{~cm}$ masses at the upper right frontal part and left temporal region of his skull (nodular and solid tumour under the skin on the bone and infiltrated to bone) (Figure $1 \mathrm{~A}$ ), and a $2 \times 2 \mathrm{~cm}$ mass in the sternum 4 th- 5 th intercostal gap.

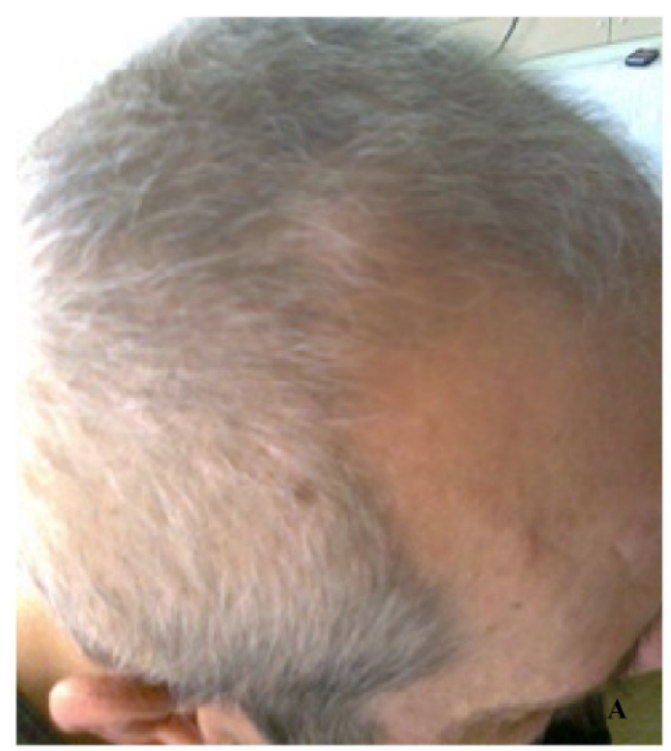

Figure 1 (A): $2 \times 3 \mathrm{~cm}$ masses at the upper right frontal part and left temporal region of his skull.

His abdominal tomography revealed subdermal soft tissue lesions that caused destruction in the bone tissue in the vertex right lateral and 
left parietal region in the cranium. His positron emission tomography revealed increased fluorodeoxyglucose (FDG) involvement in the subdermal soft tissue lesion that caused destruction with an area of 16 $\times 20 \mathrm{~mm}$ in the vertex right lateral in cranium, lytic lesion region and left parietal region, and multiple focuses as masses causing destruction in bone structures (Figure 1B). The patient's M-spike was $0.33 \mathrm{gr} / \mathrm{dl}$, and his bone marrow aspiration revealed that the ratio of his plasma cells was $10 \%$. His bone marrow biopsy revealed widespread atypical plasma cell infiltration. During the patient's stay at the hospital, he developed a $3 \times 4 \mathrm{~cm}$ plasmacytoma on his left ear and a $2 \times 2 \mathrm{~cm}$ plasmacytoma on the right side of his forehead. Since the disease progressed, the patient was given Dexamethasone, Cisplatin, Etoposide, Cyclophosphamide and Bortezomid treatment. It was seen that the swellings completely disappeared one week after the treatment. Autologous transplant was performed on the patient. The patient is being followed up by the polyclinic without any problem.

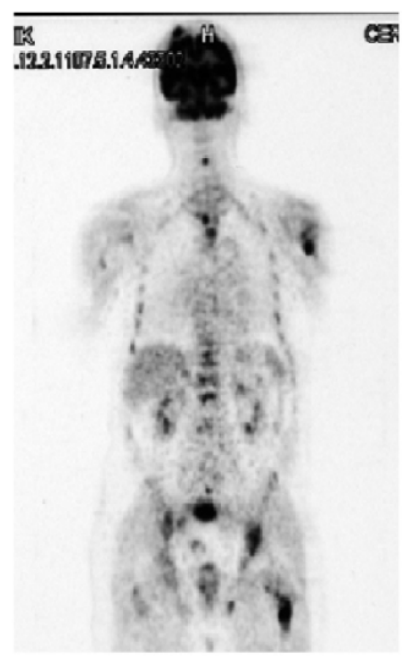

Figure 1 (B): Fluorodeoxyglucose involvement in the subdermal soft tissue lesion that caused destruction with an area of $16 \times 20 \mathrm{~mm}$ in the vertex right lateral in cranium.

\section{Discussion}

Plasma cell neoplasms include multiple myeloma (MM), monoclonal gammopathies of unknown significance, plasmacytomas and plasma cell leukaemia. MM is the most common of the plasma cell neoplasms. Whereas MM represents systemic disease, plasmacytomas represent local forms of plasma cell neoplasms. Plasmacytoma is further classified into two groups: osseous [Solitary plasmacytoma of bone-(SPB)] and non-osseous [Extra medullary plasmacytoma (EMP)] primary lesions [1].

Plasmacytomas represent less than $1 \%$ of all head and neck tumours [2]. However, the majority (80\%) of EMP occur in the head and neck, especially the nasopharynx and the paranasal sinuses [3,4]. Rare cases of primary EMP have been described in the skull, larynx, hypopharynx, parotid gland, submandibular gland, thyroid, mandibular region, trachea, oesophagus, cervical lymph nodes, middle ear, orbit, scalp, forehead, palate, tongue and mastoid [1,2].

Skull lesions are usually asymptomatic, but larger tumours can cause symptoms. Intracranial involvement generally results from extra medullary tumour masses arising from bone lesions in the cranial vault, skull base, nose, or paranasal sinuses [5]. Notably, plasma cell tumour dural deposits usually result from direct spread from contiguous bone lesions. Myelomatous deposits in dural reflections distant from the bony skull, i.e. tentorium and falx, are rarer, and probably result from dissection along layers of meninges [6]. Osseous and pachymeningeal masses in the cranial vault or in the skull base may result in tumefaction, pain, headache, single or multiple cranial nerve palsies, or seizure [5,7]. Involvement of the orbits may result in orbital pain and exophthalmos. The more relevant presenting features of leptomeningeal MM include paraparesis, symptoms from increased intracranial pressure, cranial nerve palsies (particularly nerves $\mathrm{V}$ and IV), convulsions and confusion [7]. Furthermore, encephalopathy and cranial nerve palsies may also result from metabolic derangements such as hypercalcemia and uremia, antibodies directed against myelin structures, amyloid deposits, and hyperviscosity syndrome, in addition to treatment-related toxicity and complications [5].

If anatomically suitable, the primary therapy mode for plasmacytomas is surgery followed by irradiation, since the tumour is exquisitely radiosensitive. In calvarial lesions, cure is generally achieved by complete surgical resection followed by at least 50 Gy radiotherapy. Lesions at the skull base are treated by biopsy and/or subtotal resection followed by irradiation, or irradiation alone [8]. Radiosurgery with a relatively low dose of $14 \mathrm{~Gy}$ has been reported to be appropriate when the tumor or tumor remnant volume is suitable [5]. Systemic therapy, such as chemotherapy or autologous stem cell transplantation, is recommended for refractory, recurrent, and multiple plasmacytomas [5]. The survival of patients with MM ranges from several months to more than 10 years, depending on disease stage at diagnosis and laboratory prognostic factors. Patients with intracranial MM have been reported to survive for 1 to 96 months after diagnosis. Patients with $\mathrm{MM}$ at the skull base have a median life expectancy of 3 years, while leptomeningeal myelomatosis generally has a poor prognosis despite aggressive systemic and local therapy [7].

In conclusion although high-dose chemotherapy followed by autologous or allogenic stem cell transplantation has improved prognosis, patients with $\mathrm{MM}$ at the skull base have a poor prognosis. In our case multiple myeloma relapsed with extramedullary plasmacytoma in the skull, forehead and ear involvement improved with high-dose chemotherapy followed by autologous stem cell transplantation.

\section{References}

1. Pancholi A, Raniga S, Vohra P, Vaidya V, Prajapati A, et al. (2006) "Imaging Features Of Extramedullary Plasmacytoma Of Skull Base With Multiple Myeloma" A Rare Case. Ind J Radiol Imag 16: 29-32.

2. Nofsinger YC, Mirza N, Rowan PT, Lanza D, Weinstein G (1997) Head and neck manifestations of plasma cell neoplasms. Laryngoscope 107: 741-746.

3. Bolek TW, Marcus RB Jr, Mendenhall NP (1996) Solitary plasmacytoma of bone and soft tissue. Int J Radiat Oncol Biol Phys 36: 329-333.

4. Som PM, Brandwein MS (2003) Tumors and tumor-like conditions. In: Som PM, Curtin HD, eds. Head and Neck Imaging, Vol. 1, 4th ed. St. Louis: Mosby, 261-373.

5. Cerase A, Tarantino A, Gozzetti A, Muccio CF, Gennari P, et al. (2008) Intracranial involvement in plasmacytomas and multiple myeloma: a pictorial essay. Neuroradiology 50: 665-674.

6. Roddie P, Collie D, Johnson P (2000) Myelomatous involvement of the dura mater: a rare complication of multiple myeloma. J Clin Pathol 53: 398-399. 
Citation: Kayar Y, Kayar NB, Ekinci I, Coban G, Unver N (2016) Multiple Myeloma Relapsed with Skull Involvement in Plasmacytoma. J Carciong Mutagen 7: 273. doi:10.4172/2157-2518.1000273

Page 3 of 3

7. Bladé J, Rosiñol L (2007) Complications of multiple myeloma. Hemato Oncol Clin North Am 21: 1231-1246.
8. Higurashi M, Yagishita S, Fujitsu K, Kitsuta Y, Takemoto Y, et al. (2004) Plasma cell myeloma of the skull base: report of two cases. Brain Tumor Pathol 21: 135-141. 